DOI : $10.14746 / \mathrm{pp} .2017 .22 .2 .4$

Ireneusz Paweł KAROLEWSKI, Thomas MEHLHAUSEN

\title{
Między polityką kreowania a asertywnością. Polskie debaty o Europie na przykładzie europejskiego traktatu konstytucyjnego i wojny na Ukrainie
}

\begin{abstract}
Streszczenie: Artykuł analizuje fenomen polityzacji na przykładzie obrazów Europy w politycznym dyskursie Polski w latach 1990-2016. Autorzy wychodzą od fazowego modelu polskiej polityki europejskiej (adaptacja, kontestacja, kooperacja, suwerenizm) i argumentują, że zmiana wewnątrzpolitycznych relacji władzy w Polsce nie jest wystraczającym wyjaśnieniem dla dynamiki faz polskiej polityki europejskiej. Z tego względu analizie poddane są obrazy Europy, z którymi związane są różne potencjały polityzacyjne. Po przedstawieniu konceptualizacji obrazów Europy przeanalizowane zostaną dwa przypadki znajdujące się w fazach konfrontacji i suwerenizmu, które to wykazują duży stopień polaryzacji politycznej: debata o europejskim traktacie konstytucyjnym (2005) oraz polityka wschodnia w trakcie wojny na Ukrainie (2014). Analiza potwierdza, że w przypadku Polski głównymi podmiotami polityzacji pozostają partie polityczne. Poprzez silną polaryzację obrazów Europy na poziomie elit politycznych odzwierciedlane są z jednej strony zróżnicowane nastroje społeczne. Równocześnie, silna polaryzacja powoduje, że nawet w ramach jednej partii politycznej widoczna jest silna dynamika polityzacyjna, a obrazy Europy cechują się wysoką niestabilnością.
\end{abstract}

Słowa kluczowe: Polska polityka europejska, obrazy Europy, partie polityczne, polityzacja, polaryzacja, wojna na Ukrainie, europejski traktat konstytucyjny

\section{Wprowadzenie}

D olską politykę europejską III Rzeczpospolitej Polskiej (1990-2016) można podzielić na kilka faz: adaptacji, kontestacji, kooperacji i suwerenizmu (Mehlhausen, 2009) ${ }^{1}$. W fazie adaptacji (1990-2002) niemal wszystkie partie polityczne dążyły do szybkiego przystapienia Polski do UE. Jako państwo kandydujące, Polska musiała bezkompromisowo przyjąć wszystkie przepisy UE (,acquis communautaire”), bez możliwości wpływu na nie. Jednak im bardziej konkretne stawały się negocjacje, tym bardziej widoczne stawały się także potencjalne koszty wstąpienia do UE. Spowodowało to, że w roku 2001 do Sejmu weszły po raz pierwszy eurosceptyczne partie politycznie, a dotychczasowy konsensus polityczny w sprawie ,braku alternatywy” dla członkostwa w UE załamał się.

Faza kontestacji (2002-2007) rozpoczęła się burzliwym zakończeniem negocjacji akcesyjnych w grudniu 2002 roku, kiedy to Polska nalegała na dodatkowy miliard euro $^{2}$. Jeszcze podczas Konwentu Europejskiego (od lutego 2002 do czerwca 2003 roku)

${ }^{1}$ Artykuł ten ukazał się pierwotnie w języku niemieckim pod tym samym tytułem w następującym tomie zbiorowym: L. Andersa, H. Scheller, T. Tuntschew (red.) (2016), Parteien und die Politisierung der Europäischen Union, VS-Verlag.

2 Takie dodatkowe płatności określa się $\mathrm{w}$ terminologii politologicznej jako side-payments i są to transakcje finansowe, które przy zablokowanych negocjacjach prowadzą do osiągnięcia kompromisu. 
Polska, bez prawa głosu, zgłosiła w grudniu 2003 roku - przed formalnym wejściem do $\mathrm{UE}^{3}$ - weto do Traktatu ustanawiającego Konstytucję dla Europy (TKE). Mimo, że pół roku później możliwe było osiagnięcie kompromisu, to w roku 2007 (nowy) polski rząd zagroził ponownie użyciem weta w sprawie nieznacznie zmodyfikowanego traktatu lizbońskiego, ostatecznie go jednak nie wnosząc (Mehlhausen, 2009).

Późniejszą fazę kooperacji (2007-2015) ukształtowały w znacznym stopniu rządy Platformy Obywatelskiej, na czele z Donaldem Tuskiem, który sukcesywnie łagodził tlące się konflikty i okazał się wiarygodnym i gotowym do kompromisów partnerem, szczególnie podczas kryzysu euro. Również podczas sprawowania prezydencji Rady UE przez Polskę w drugiej połowie roku 2011, koalicja rządząca, mimo równolegle odbywających się wyborów parlamentarnych, nie dała się nakłonić do nadmiernego reprezentowania interesów narodowych, ale opowiedziała się poprzez przewodnictwo w Radzie na rzecz wspólnoty europejskiej (Karolewski, Mehlhausen, Sus, 2014). Dodatkowo sprzyjał temu fakt, że opozycja ze swoimi eurosceptycznymi postulatami pozostała w kampanii do wyborów prezydenckich w roku 2010 i parlamentarnych w roku 2011 w cieniu.

Okazało się to tylko tymczasowym rozejmem w polityce europejskiej. Podwójne zwycięstwo Prawa i Sprawiedliwości (PiS) w wyborach prezydenckich i parlamentarnych w roku 2015 zapoczątkowało fazę suwerenizmu. Świeżo wybrana premier Beata Szydło (PiS) podkreśliła, że będzie reprezentować w UE głównie interesy Polski (Vetter, 2015, s. 4) ${ }^{4}$. W najbardziej palącej obecnie kwestii w polityce europejskiej, a mianowicie polityce imigracyjnej i azylowej, Polska nalega na rozwiązania narodowe, a nie europejskie. Nowa reforma konstytucji i mediów rządu PiS doprowadziła jednocześnie do masowych protestów, zaś Komisja Europejska rozpoczęła procedurę sprawdzenia zgodności proponowanych projektów ustaw z prawem europejskim (Karolewski, Benedikter, 2016a).

Z pewnością zmiany w polskiej polityce europejskiej można wyjaśnić częściowo zmianą rządu. W obu fazach: kontestacji i suwerenizmu u władzy było nastawione bardziej sceptycznie do polityki europejskiej Prawo i Sprawiedliwość. Jednak wytłumaczeniem dla obu tych faz nie jest tylko zmiana polityczna na szczeblu wewnątrzpaństwowym, ponieważ fazę kontestacji w negocjacjach akcesyjnych zainicjował pro-europejski Sojusz Lewicy Demokratycznej, doprowadzając ją do punktu kulminacyjnego poprzez swoje weto w sprawie Traktatu Konstytucyjnego. Niezbędne jest zatem dokładniejsze przyjrzenie się dynamice poglądów dotyczących polityki europejskiej w Polsce, w której łączą się odmienne potencjały polityzacyjne. Ich analizę poprzedzi teoretyczny wstęp do koncepcji obrazów Europy. W tym względzie zbadane zostaną dwa studia przypadku, przypadające na dwie kontrowersyjne fazy: kontestacji i suwerenizmu i wskazujące na wysoki stopień polaryzacji - debata dotycząca Europejskiego Traktatu Konstytucyjnego (2005) i polityka wschodnia w trakcie wojny na Ukrainie (2014).

3 Już na mocy podpisania w kwietniu 2013 roku Traktatu o Przystąpieniu do UE, Polska uzyskała możliwość wpływu na decyzje konstytucyjne w UE.

${ }^{4}$ W pierwszej konferencji prasowej Beaty Szydło brakowało ponadto flagi europejskiej. Niektórzy obserwatorzy zinterpretowali to jako symboliczny znak nowego eurosceptycyzmu, przy czym zarówno w biurze Szydło, jak i w sali obrad rządu nadal znajdowała się flaga UE, a wcześniejsi premierzy Donald Tusk i Ewa Kopacz udzielali niektórych konferencji prasowych tylko z polską flagą w tle. 


\section{Dyskurs konstruktywistyczny na temat obrazu Europy}

Wraz z pojawieniem się konstruktywizmu w badaniach nad Europą pod koniec lat 90-tych XX wieku rozwinął się dział badań, który stosując odmienne terminologicznie, ale podobne semantycznie koncepcje zajmował się wizjami narodowymi dotyczącymi przyszłej integracji europejskiej. Poniżej chcemy omówić „obrazy Europy” definiowane przez Susanne Klunkert i Ludmilę Eckertovą (1996, s. 13) jako „idee i wyobrażenia Europy oraz koncepcje polityczne Europy". Heinrich Schneider (1996, s. 56) wyróżnia trzy rodzaje obrazów Europy: „Obrazy tego, co jest, obrazy tego, czego się faktycznie oczekuje lub obawia oraz obrazy tego, co jest pożądane, do czego się dąży i uważa za możliwe do zrealizowania również przy użyciu własnych sił”. Oprócz tej koncepcji obrazów Europy jako charakterystyki teraźniejszości lub wizji przyszłości koncepcje takie mogą według Heinza Gollwitzera (1964, s. 12) obejmować również specyficzną historyczną kulturę pamięci w sensie „historii uniwersalnej i Europy w kontekście polityki światowej”. Chociaż te trzy wymiary pojęcia nierzadko ściśle się ze sobą łączą, obrazy Europy w niniejszej publikacji rozumiane są w sensie normatywnych koncepcji przyszłego, prawnego kształtu UE. Zakładamy ponadto, że zgodnie z paradygmatem liberalnym, polityka zewnętrzna nie jest determinowana zewnętrznie przez anarchię międzynarodową (Waltz, 1979), ale działania w polityce zewnętrznej są zależne od danej konstelacji podmiotów w polityce wewnętrznej. Nie są one jednak siłą rzeczy motywowane wyłącznie utylitarystycznie (Putnam, 1988; Moravcsik, 1998), ale są zależne od przekonania co do legitymacji określonych struktur instytucyjnych oraz od postrzegania innych podmiotów międzynarodowych (Wendt, 1992, 1999).

Na przełomie wieków powstało szereg opracowań dotyczących poszczególnych państw o takim teoretycznym charakterze. Uwagę skupiono jednak wyłącznie na dużych krajach, takich jak Niemcy (Jachtenfuchs, 2002), Francja (Jung, 1999), Wielka Brytania (Larsen, 1997; Diez, 1999) i Polska (Hahn, 2007; Münch, 2007) lub na porównaniu pomiędzy tymi krajami (Marcussen i in., 2001; Wagner, 2002). W dalszych pracach wykorzystywano na wstępie to początkowo deskryptywne podejście do wyjaśnienia decyzji integracyjnych, jak np. traktatu z Maastrich (Jachtenfuchs, 1998; Risse, 1999). Wartością dodaną podejścia konstruktywistycznego jest to, że umożliwia ono wyjaśnianie także takich decyzji, które nie opierają się na racjonalnej kalkulacji kosztów i zysków, jak np. zgoda Niemiec dla unii gospodarczej i walutowej (Marcussen i in., 2001). Niemniej jednak można dostrzec różnice w operacjonalizacji pojęć, ponieważ niektóre opracowania identyfikują narodowy obraz Europy, inne z kolei obrazy Europy w zależności od partii politycznych. Jest to zagadnienie empiryczne: O ile w przypadku Niemiec występuje daleko idący ponadpartyjny europejski konsensus polityczny w kwestii podstawowych zagadnień integracji europejskiej - a więc niemiecki obraz Europy (z wyjątkiem AFD i Linke), o tyle w Polsce dominują od kilku lat raczej różnice, przez co nie można wyłonić jednolitego polskiego obrazu Europy. Dlatego koncepcja obrazu Europy musi być sprecyzowana w odniesieniu do wybranych podmiotów. Ze względu na wybraną perspektywę podmiotową (w przeciwieństwie do np. instytucjonalnej), skupiamy się w niniejszym artykule na obrazach Europy polskich partii politycznych. 


\section{Typy idealne obrazów Europy: model federacji, wspólpracy i autonomii}

W przeciwieństwie do istniejących badań, nie chcemy jednak określać obrazów Europy indukcyjnie na podstawie debat publicznych, ale zdefiniować je raczej dedukcyjnie jako typy idealne (w rozumieniu Maxa Webera) w celu wygenerowania w debacie na temat upolitycznienia określonej miary dla polaryzacji poglądów dotyczących polityki europejskiej pomiędzy partiami politycznymi. Spektrum obrazów Europy w Polsce rozciagga się od koncepcji federalnych aż po izolacjonistyczne. W oparciu o pracę Holgera Müncha (2007; ale także Hahn, 2007) wyróżniamy model federacji, współpracy i autonomii i zawyżamy je świadomie do typów idealnych o charakterze kontrfaktycznym. Charakteryzujemy te modele pod względem relacji pomiędzy pojęciem Europy a pojęciem Unii Europejskiej, funkcji państwa narodowego w ramach integracji europejskiej, planowanego ostatecznego efektu procesu unifikacji oraz zakładanej motywacji do integracji.

Tabela 1

Wyidealizowane modele federacji, współpracy i autonomii

\begin{tabular}{|l|l|l|l||}
\hline \hline $\begin{array}{l}\text { Relacja pomiędzy Europą } \\
\text { a UE }\end{array}$ & $\begin{array}{l}\text { Model federacji } \\
\text { zerspektywicznie }\end{array}$ & Model wspólpracy & \multicolumn{1}{|c||}{ Model autonomii } \\
\hline $\begin{array}{l}\text { Funkcja państwa narodo- } \\
\text { wego }\end{array}$ & $\begin{array}{l}\text { integracja wykra- } \\
\text { cza poza państwo } \\
\text { narodowe }\end{array}$ & $\begin{array}{l}\text { integracja uzupełnia } \\
\text { państwo narodowe }\end{array}$ & $\begin{array}{l}\text { integracja pełni funkcję instrumen- } \\
\text { tu władzy potężnych państw naro- } \\
\text { dowych }\end{array}$ \\
\hline $\begin{array}{l}\text { Planowany ostateczny } \\
\text { efekt procesu unifikacji }\end{array}$ & $\begin{array}{l}\text { zjednoczone Stany } \\
\text { Europy }\end{array}$ & Europa ojczyzn & lad westfalski \\
\hline $\begin{array}{l}\text { Zakładana motywacja do do } \\
\text { integracji }\end{array}$ & $\begin{array}{l}\text { oparta na warto- } \\
\text { ściach }\end{array}$ & $\begin{array}{l}\text { zorientowana na ko- } \\
\text { rzyści }\end{array}$ & hegemonialna \\
\hline
\end{tabular}

Źródło: Opracowanie własne na podstawie Münch, 2007.

W modelu federacji integracja europejska rozumiana jest jako osiagnięcie cywilizacyjne służące pokonaniu rozbicia na małe partykularne państwa i konfliktowości państw narodowych. Według mitu założycielskiego z lat 50-tych XX wieku jest to wizja integrująca, panaeuropejska i pokojowa. Państwo w sensie zjawiska uwarunkowanego historycznie jest akceptowane jako obecnie najważniejszy szczebel polityczny, jednakże federaliści wychodzą z założenia, że własna dynamika integracji będzie go sukcesywnie transcendowała - jak chociażby w funkcjonalistycznej logice metody Monneta. Efektem końcowym będzie europejskie państwo federalne - w sensie koncepcji „Zjednoczonych Stanów Europy" Churchilla - w którym państwo narodowe stanowi zgodnie z zasadą pomocniczości tylko jeden $\mathrm{z}$ wielu poziomów terytorialnych. Integracja europejska jest wspierana ze względów normatywnych: wysiłki integracyjne oparte są w mniejszym stopniu na oczekiwanej rozwiązywalności problemów społeczno-ekonomicznych, ale bardziej na sile przekonania stale zacieśniającej się i solidarnej wspólnoty wartości cechującej się silną tożsamością zbiorową, która po stworzeniu odpowiednich instytucji federalnych mogłaby się rozwijać procesualnie.

Model współpracy oddziela pojęcie Europy od pojęcia Unii Europejskiej, ponieważ ta ostatnia jest jedynie wzajemnie korzystną formą współpracy międzypaństwowej 
i można ją określić mianem celowego stowarzyszenia funkcjonalnej integracji (Ipsen, 1972, s. 196). Nie jest jednak wykluczone, że UE obejmie w przyszłości cały kontynent europejski. Państwo pozostaje tutaj kluczowym uczestnikiem, również dlatego, że ze względu na swoje cechy pierwotne, takie jak język, kultura pamięci i tradycje kulturowe, może z największym prawdopodobieństwem wygenerować tożsamość zbiorową i solidarność. Integracja jest popierana tak długo, jak długo postrzegana jest w rachunku utylitarystycznym jako korzystna. Państwa członkowskie pozostają jednak również w perspektywie długoterminowej ,panami traktatów” przy zachowaniu zasady jednomyślności we wszystkich wrażliwych obszarach polityki - zgodnie z wizją „Europy ojczyzn" Charles'a de Gaulle'a bądź też w kategorii teoretycznego modelu integracji politycznej zgodnie z teorią ,principal-agent”. Mimo przekazania określonych kompetencji instytucjom ponad-narodowym, takim jak Komisja Europejska, państwa członkowskie są w stanie je kontrolować (Kassim, Menon, 2003). Może temu towarzyszyć renacjonalizacja już zintegrowanych obszarów polityki i może to również implikować zobowiązania do wzajemnej pomocy, jednakże przy wyraźnym zachowaniu idei przydatności (Scharpf, 1999). Dochodzą tutaj także wątpliwości związane z demokracją dotyczące jej deficytu w odniesieniu do struktur UE, który ze względu na brak europejskiej przestrzeni publicznej i partii europejskich nie tylko czyni Unię Europejską niezdolną do w pełni demokratycznego funkcjonowania, ale także osłabia demokracje państwowe poprzez przesuwanie kompetencji na poziom unijny. Tym samym Unia Europejska staje się zagrożeniem dla demokratycznej suwerenności państw członkowskich (Grimm, 2015).

W modelu autonomii krytycznie postrzega się zarówno Europę w sensie kulturowohistorycznym, jak i instytucjonalną konstrukcję Unii Europejskiej. Historię Europy charakteryzowały przez długi czas wojny oraz obce panowanie i pozostaje ona nadal tylko polem bitwy w środowisku międzynarodowej anarchii. UE postrzegana jest natomiast jako sterowany przez duże państwa - przede wszystkim Francję i Niemcy - neo-hegemonialny system władzy i powinna w związku z tym obejmować jak najmniejszą część kontynentu europejskiego. Państwo narodowe uważa się natomiast za ostoję wolności przede wszystkim narodów definiowanych etnicznie, które powinny respektować się wzajemnie w pokojowym współistnieniu, zgodnie z ładem westfalskim, chroniąc przy tym w miarę możliwości swoją autonomię.

\section{Obrazy Europy wśród polskich partii polityeznych}

Ta szeroka gama obrazów Europy jest konieczna, aby określić polaryzację w kwestii polityki europejskiej w polskim krajobrazie politycznym. Podczas gdy w Niemczech przykładowo jeszcze do niedawna wszystkie partie stale reprezentowane w Bundestagu można było przypisać raczej do modelu federacji niż do modelu współpracy, a za modelem współpracy opowiada się obecnie co najwyżej Alternatywa dla Niemiec (AfD), polskie partie polityczne na przestrzeni ostatnich 14 lat reprezentowały całe spektrum koncepcji Europy.

Skupiamy się poniżej na latach 2002-2016, ponieważ w pierwszej fazie, fazie adaptacji, nie tylko panował daleko idący konsensus wśród polskich partii politycznych oraz wysoka fluktuacja w polskim systemie partyjnym, ale Polska nie mogła także mieć 
kształtującego wpływu w UE. Bierzemy zatem pod uwagę pięć okresów legislacyjnych, w których cztery partie polityczne reprezentowane były stosunkowo stabilnie w rządzie i przejmowały na przemian odpowiedzialność rządową: Sojusz Lewicy Demokratycznej (SLD) ${ }^{5}$, Polskie Stronnictwo Ludowe (PSL), Prawo i Sprawiedliwość (PiS) oraz Platforma Obywatelska (PO). Tych partii dotyczy poniższa grafika. Pięć pozostałych, mniejszych partii politycznych potraktowano marginalnie, gdyż zasiadały one w sejmie przez maksymalnie tylko dwa okresy legislacyjne: Samoobrona (SRP), Liga Polskich Rodzin (LPR), Twój Ruch (TR)', Nowoczesna (N) i Kukiz '15. Mniejszość niemiecka - niezależnie od wyników wyborów - posiadała zawsze jeden mandat i stąd pominięto ją w dalszej analizie. Poniższy diagram (Wykres 1) przedstawia rozkład obrazów Europy w poszczególnych okresach legislacyjnych począwszy od roku 2001.

\section{Wykres 1. Podział obrazów Europy reprezentowanych przez partie polskie w Sejmie od roku 2001}

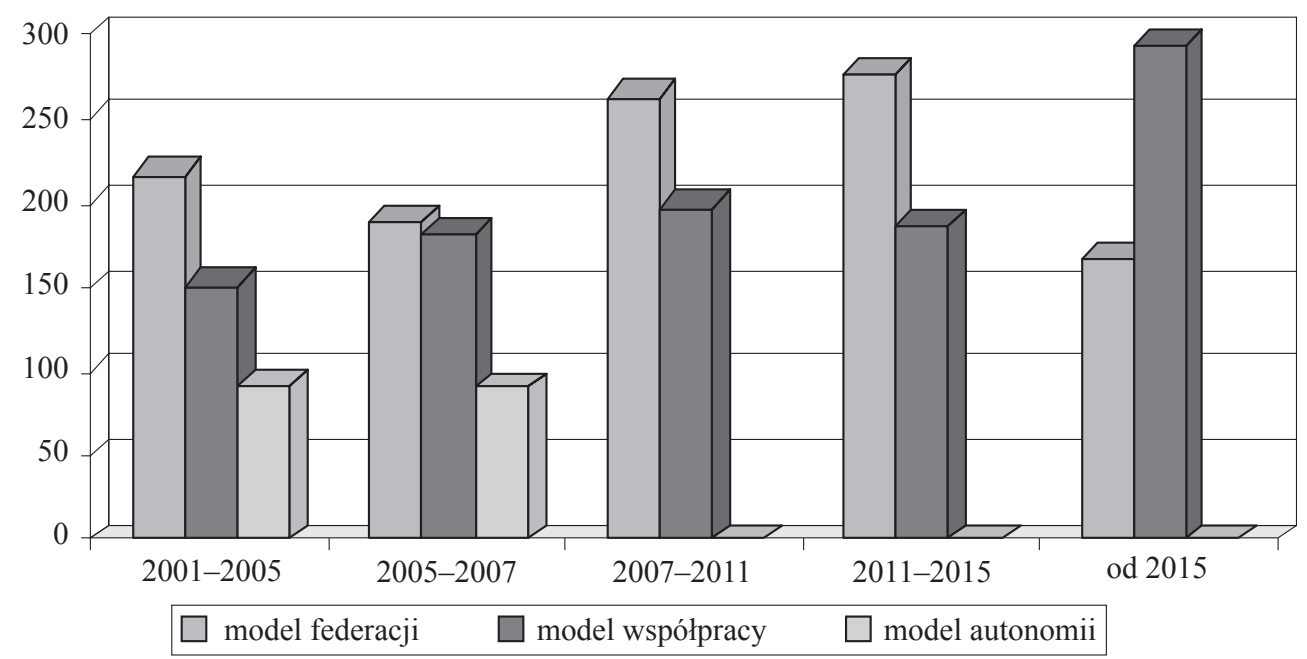

Źródło: Opracowanie własne.

W pierwszej kolejności dokonamy przyporządkowania poszczególnych partii politycznych do scharakteryzowanych powyżej modeli, w szczególności pod względem ich stanowiska w debacie dotyczącej przystapienia Polski do UE (Münch, 2007; Hahn, 2007), aby następnie przedstawić dynamikę w obrębie samych obozów politycznych i na końcu określić wspólne cechy narodowe w odniesieniu do „polskiego obrazu Europy”.

Model federacji można przypisać partiom lewicowo-liberalnym. Szczególną cechą polskiego systemu partyjnego jest to, że podział wzdłuż schematu lewicowo-prawicowego jest możliwy w ograniczony sposób, ponieważ chociażby w przypadku PiS sta-

${ }^{5}$ Partia ta wraz z kilkoma mniejszymi partiami tworzyła kilka koalicji wyborczych - na przykład pod nazwą Lewica i Demokraci (LiD) lub Zjednoczona Lewica (ZL). Dla zachowania przejrzystości wyniki wyborów tych koalicji przypisujemy największemu koalicjantowi - SLD. Jako jedyna z czterech utworzonych partii SLD nie wszedł ponownie do parlamentu w roku 2015, uzyskując wynik nieco poniżej wymaganego 8-procentowego progu wyborczego.

${ }^{6}$ Pierwotnie partia ta nazywała się Ruch Palikota (2010-2013). 
nowiska konserwatywne idą w parze z postulatami działań politycznych o szerokim charakterze redystrybucyjnym (Karolewski, Benedikter, 2016b). Określenie „lewicowoliberalny" odnosimy zatem do kwestii ideologicznej dotyczącej sceptycznego podejścia do tradycyjnych wartości i narodu oraz prymatu wolności jednostki. Analizą nie będą przy tym wyraźnie objęte kwestie dotyczące sprawiedliwości dystrybutywnej.

Partią polityczną najbliższą modelowi federacji jest postkomunistyczny SLD, przy czym w zależności od jego odłamów istnieje również wiele odniesień do modelu współpracy. Jak określiła Irene Hahn w swojej analizie debaty akcesyjnej ,terminu Europa używa się bardzo często jako synonimu Unii Europejskiej” (Hahn, 2007, s. 41). Z jednej strony z Unią Europejską kojarzony jest pewien określony zbiór wartości, z drugiej strony postrzega się, głównie w rachunku ekonomicznym, brak alternatywy dla członkostwa w niej oznaczającego nieodzowny impuls modernizacyjny. Istnieją zatem pewne sprzeczności między biegunami Unii Europejskiej jako osiagnięcia cywilizacyjnego i Unii Europejskiej jako ,pola gry interesów” (Józef Oleksy cytowany przez Hahn, 2007, s. 41). Do pierwszego poglądu zaliczyć można głosy takie, jak opinia ówczesnego premiera Millera, że UE ,zmierza w kierunku federacji” (Münch, 2007, s. 70). Z drugiej strony, UE traktowana jest jako forum do realizowania interesów narodowych, nie dominuje w niej solidarność, ale interesy narodowe i władza silniejszego. Niemniej jednak, zgodnie z tezą ,voice-opportunity” (Grieco, 1996)7, oddelegowanie polskiej suwerenności „opłaca się”, gdyż w ten sposób wzrasta także wpływ Polski na inne państwa. Integracja europejska „nie jest zatem nacechowana entuzjastycznym idealizmem” (Hahn, 2007, s. 43). Jest to bardziej racjonalna kalkulacja kosztów i korzyści bez roszczeń moralnych lub uhistorycznionych argumentów. Nie antycypuje się osłabienia państwa narodowego (Iwiński cytowany przez Hahn, 2007, s. 42). Stąd też SLD domaga się również, aby pewne obszary polityki pozostawić w gestii państw członkowskich, gdyż stanowią one zasadnicze demokratyczne źródło legitymizacji UE (Münch, 2007, s. 72).

Platforma Obywatelska (PO) powstała z połączenia byłych członków liberalnej Unii Wolności (UW) i konserwatywnej Akcji Wyborczej „Solidarność” (AWS) i ma od tego czasu te dwa odłamy: w latach 2001-2005 ówczesny lider parlamentarny Jan Maria Rokita reprezentował konserwatywny i mniej proeuropejski odłam PO, a wieloletni przewodniczący partii Donald Tusk uosabiał bardziej pro-europejski kurs odłamu gospodarczo-liberalnego. Kurs europejski PO uległ radykalizacji szczególnie w trakcie debaty na temat Traktatu Konstytucyjnego (TKE), czego przykładem było sztandarowo cytowane hasło „Nicea albo śmierć”. PO nalegała także na prawo weta dla wszystkich państw członkowskich i odrzucało rozkład głosów uzależniony w większym stopniu od wielkości populacji (Münch, 2007, s. 71). Podczas gdy partia oscylowała dotąd pomiędzy modelem federacji a modelem współpracy, od roku 2005, gdy jej przewodnictwo objął Tusk, jej politykę zdominował odłam pro-europejski ${ }^{8}$. Kierując rządem (2007-2015) PO próbowała świadomie odpolityczniać konflikty w UE i realizować poprzez pragmatyzm

${ }^{7}$ Zgodnie z neo-realistyczną tezą „,voice-opportunity” państwo jest zainteresowane dalszą integracją wtedy, gdy związana z nią rezygnacja $\mathrm{z}$ autonomii jest zrekompensowana dodatkowym wpływem na decyzje innych państw.

${ }^{8}$ PO nie można przypisać jednoznacznie do jednego modelu. Hahn $(2007$, s. 43) przypisuje tą partię do euro-realistów (czyli do modelu współpracy), natomiast Münch (2007, s. 69) klasyfikuje PO jako przedstawiciela modelu federacji. 
kooperacyjny celowo interesy narodowe, chociażby w polityce klimatycznej czy polityce spójności, nie przedstawiając tego jako walki z zewnętrznym wrogiem - czy to z Unią Europejską czy też z poszczególnymi państwami członkowskimi. Symbolem przemiany PO było wreszcie także mianowanie jej wieloletniego przewodniczącego, Donalda Tuska, na przewodniczącego Rady Europejskiej.

Spośród mniejszych partii politycznych do modelu federacji można przypisać Unię Pracy (UP), aczkolwiek współtworzyła ona rząd tylko w okresie legislacyjnym 2001-2005 w koalicji z SLD. W następnych wyborach nie osiagnęła 5-procentowego progu wyborczego i została rozwiązana w roku $2008^{9}$.

\section{Model współpracy}

Model współpracy reprezentują w Polsce partie opowiadające się za polityką opartą na wartościach konserwatywnych. Wpływowym politycznie ,adwokatem” tego modelu w UE jest PiS, ale także PSL jako stały koalicjant gwarantujący sejmową większość reprezentuje ten obraz Europy. Do modelu tego można również zaszeregować PO, przynajmniej to będące pod wpływem Rokity do roku 2005.

Punktem wyjścia w tym modelu jest zdystansowany stosunek do UE. Integracja europejska wcale nie jest przedstawiana jako projekt cywilizacyjny, stąd też Europa nie jest utożsamiana z UE. Polska jest natomiast postrzegana jako część Europy, ale nie każde państwo europejskie musi koniecznie wstapić do UE. UE jest raczej definiowana jako instytucja specyficznie zachodnioeuropejska, mająca dla danego państwa członkowskiego zarówno zalety jak i wady.

Zadaniem państwa jest przy tym ochrona narodu, która nie może być oddelegowana do organizacji ponadnarodowej (Kaczyński, 2003, s. 18). Dla PiS Polska jest „państwem walczącym o pozycję narodu w Europie i świecie i stale zabiegającym o jej umocnienie" (Kaczyński, 2003, s. 32). Jest to jednak również możliwe w ramach członkostwa w UE. Jeśli chodzi o porządek instytucjonalny UE, wymienione wyżej partie nie przeciwstawiają się członkostwu w UE, ale akceptują oddelegowanie suwerenności - jeśli w ogóle - tylko z pewnymi zastrzeżeniami i odnosząc się do doświadczeń historycznych, jak np. takimi, że Bruksela nie powinna być drugą „Moskwą”. Przedstawiciele tego podejścia postulują zatem za prymatem państwa narodowego jako normatywnej podstawy jakiejkolwiek integracji instytucjonalnej, a tym samym za międzyrządowym trybem decydowania. Umocnienie pozycji UE w określonych sektorach może być wspierane jako użyteczne, jednak nieodzownym warunkiem jakiejkolwiek integracji jest zachowanie nadrzędnej kompetencji państw członkowskich.

Podczas gdy takie rozumienie jest podzielane również przez inne partie, przypisywane do tego modelu, w przypadku PiS wyróżnia się akcentowanie wymiaru moralnohistorycznego (Hahn, 2007, s. 48). PiS wywodzi zatem prawo do członkostwa w UE z (pośredniej) współwiny Niemiec i Francji za konferencję jałtańską. Jeśli w związku $\mathrm{z}$ tym żąda się solidarności w UE, to jest to jednak w pewnym sensie sprzeczne z tradycyjnym akcentowaniem interesów narodowych.

${ }_{9}$ Dla partii politycznych obowiązuje w Polsce 5-procentowy, dla koalicji wyborczych 8-procentowy próg wyborczy. 
W odniesieniu do obozu politycznego najbliżej związanego z modelem współpracy, można zaobserwować pewną zasadniczą stałą cechę, mimo że retoryczna ofensywność z nią związana charakteryzuje się jednak pewnymi wahaniami. Są to generalne zastrzeżenia PiS odnoszące się do integracji europejskiej i ograniczania suwerenności narodowej. Na przestrzeni czasu można jednak wyróżnić tutaj dwie tendencje. Z jednej strony, UE postrzegana jest na płaszczyźnie merytorycznej bardziej wielowątkowo i bardziej rzeczowo. Zadziwiające jest, że podkreśla się także korzyści z członkostwa w UE, takie jak wykorzystanie funduszy unijnych czy większy dostęp do rynku dla polskich firm (Prawo i Sprawiedliwość, 2011). Ponadto krytyka UE nie jest już tak ogólnikowa jak w debacie akcesyjnej. W tamtym czasie większość partii obawiała się, że historia się powtórzy i większe państwa ponownie wykorzystają Polskę. Obecne wypowiedzi są natomiast bardzo konkretne, np. że Polska powinna uczestniczyć w pewnym małym stopniu w ratowaniu euro i ponownie wystąpić z Paktu Euro Plus. Z drugiej strony, na płaszczyźnie retorycznej można zauważyć występowanie bardziej populistyczno-agresywnego charakteru wypowiedzi, jak chociażby w czasach gdy PiS stał na czele rządu (2005 do 2007), na przemian z dość rzeczowo-umiarkowanym tonem, jak np. bezpośrednio po zawiązaniu koalicji rządowej aż do wyborów prezydenckich, które po niej nastapiły (około 2008 do 2010). Ta niestałość może wynikać ze zmian w strategii na krajowej scenie politycznej, w wyniku których bardziej radykalne skrzydło polityczne zarzucało rywalowi politycznemu, Platformie Obywatelskiej, zdradę, a umiarkowane skrzydło „tylko” nieudolność (Flis, 2012, s. 4).

\section{Model autonomii}

Ten radykalny obraz Europy reprezentowały zaledwie dwie znaczące partie, które można określić jako prawico-populistyczne: $\mathrm{z}$ jednej strony nastawiona raczej na wyborców wiejskich Samoobrona Rzeczpospolitej Polskiej (SRP), a z drugiej strony narodowo-katolicka Liga Polskich Rodzin (LPR). Obie partie weszły do Sejmu w 2001 roku, po reelekcji w roku 2005 utworzyły koalicję rządową z PiS, jednak od wyborów w roku 2007 nie udało im się wejść ponownie do parlamentu. Obie charakteryzowały się agresywna, polemiczną i sprzeczną retoryka, typową dla partii populistycznych.

W modelu autonomii pojęcie Europy ze względu na jej chrześcijańskie korzenie zdefiniowano pozytywnie jako przestrzeń kulturową, której Polska stanowi integralną część. W przeciwieństwie do tego Unię Europejską powiązano z czymś obcym, a Brukselę - poprzez przywołanie doświadczeń realno-socjalistycznych - odrzucono jako „drugą Moskwę”. Jak argumentował Janusz Dobrosz, rząd proeuropejski musi „zawsze mieć swoich panów - kiedyś była to Moskwa, tym razem zamieniono ją na Brukselę" (Dobrosz cytowany przez Hahn, 2007, s. 48). LPR i SRP postrzegały siebie jako obrońców tożsamości narodowej przed wrogimi sąsiadami i były nastawione bardzo krytycznie przede wszystkim do Niemiec i Francji. Odrzucały zatem członkostwo w UE w debacie akcesyjnej, opowiadając się za szeroką autonomią państwa polskiego.

Podczas gdy LPR reprezentowała obraz Europy stosunkowo trwały i spójny historycznie (Hahn, 2007, s. 51), w przypadku SRP był on nie tylko mniej uzasadniony i jednolity, ale zmieniał się także znacząco. Jeszcze podczas debaty akcesyjnej SRP odrzuca- 
ła pełne członkostwo Polski w UE, natomiast potem zrelatywizowała swoje stanowisko, kwestionując konkretne warunki przystapienia do UE, aby w końcu zaakceptować ratyfikację Traktatu Konstytucyjny w Parlamencie Europejskim ${ }^{10}$. W porównaniu z LPR, która reprezentowała stabilny pogląd na świat, poglądy SRP wydawały się być raczej ukierunkowane na demoskopijne wartości elektoratu wiejskiego.

\section{Polski obraz Europy?}

Pomimo znacznych różnic pomiędzy obrazami Europy poszczególnych partii politycznych istnieją pewne wspólne cechy ponadpartyjne. W tym sensie można mówić o polskim obrazie Europy, który odnosi się jednak jedynie do relacji Polski z jej bezpośrednimi sąsiadami.

U większości partii występuje, niewątpliwie ze względów historycznych, silny sceptycyzm wobec Niemiec oraz przede wszystkim wobec Rosji, nawet jeśli retoryka konfrontacji jest zróżnicowana. Różnice można zauważyć chociażby w polityce energetycznej. Rządy post-solidarnościowe dążyły do większej niezależności od rosyjskich nośników energii w postaci terminali LNG, natomiast rządy postkomunistyczne widziały mniejsze ryzyko ze strony Rosji i odrzucały ich budowę ze względu na koszty ${ }^{11}$. Również w stosunku do Niemiec jeszcze przez długi czas panował głęboki sceptycyzm, co znalazło odzwierciedlenie w roku 2004 w jednomyślnej decyzji Sejmu przy tylko jednym głosie wstrzymującym się, aby wezwać ówczesny rząd Belki do zażądania od Niemiec odszkodowań reparacyjnych. Od 2007 roku PO obrała jednak kurs przyjazny Niemcom, co było przede wszystkim skutkiem ścisłej współpracy pomiędzy polskim premierem Donaldem Tuskiem i niemiecką kanclerz Angelą Merkel (CDU). Przykładem tego kursu jest postulat ówczesnego ministra spraw zagranicznych, Radosława Sikorskiego, z 2011 roku, że Niemcy powinny przejąć większą odpowiedzialność w UE. Jeszcze w roku 2006 Sikorski jako minister obrony narodowej porównywał budowę rurociagu bałtyckiego z paktem Ribbentrop-Mołotow.

Drugą wspólną cechą ponadpartyjną jest znaczenie Europy Środkowej, w szczególności w ramach Grupy Wyszehradzkiej tworzonej przez Polskę, Czechy, Słowację i Węgry. U wszystkich partii pojawiają się głosy, że skuteczna polityka europejska powinna być zorientowana na ten region i że Polska powinna odgrywać tutaj wiodącą rolę (Hahn, 2007, s. 41, 44, 50; Program partyjny PiS, 2011, s. 223). Nawet jeśli dotychczasowe osiagnięcia w tym zakresie są umiarkowane, a wspólne stanowisko wobec kryzysu związanego z uchodźcami na przełomie 2015/2016 roku było nietrwałe, dostrzega się tutaj w dłuższej perspektywie potencjał, który może stanowić przeciwwagę dla francusko-niemieckich ambicji przywódczych. Istnieje wreszcie też daleko idący konsensus w kwestii Ukrainy, który omówimy szerzej w dalszej części pracy. Powszechne obawy przed tendencjami neo-imperialnymi w rosyjskiej polityce zagranicznej powodują zwrot ku stabilnej, demokratycznej i pro-zachodnio ukierunkowanej Ukrainie, co zasadniczo łączy się z jej przystapieniem do UE i NATO. Wspomina się też na ogół o Białorusi i krajach bałtyckich, ale odgrywają one tylko drugorzędną rolę.

\footnotetext{
${ }^{10}$ Spośród sześciu deputowanych czterech wstrzymało się, a dwóch głosowało „za”.

${ }^{11}$ W międzyczasie zbudowano terminal LNG w Świnoujściu.
} 
Podsumowując można zatem stwierdzić, że w Polsce występuje co prawda mglisty, ponadpartyjny obraz Europy odnoszący się do Polski jako jej części i do potencjałów współpracy z jej bezpośrednimi sąsiadami, jednak konkretne wnioski z tego wynikające w odniesieniu do roli Polski w UE są bardzo rozbieżne, przez co polaryzacja w europejskim dyskursie politycznym w Polsce jest nadal znaczna.

Aby uwidocznić znaczenie tych różnych obrazów Europy dla polskiej polityki europejskiej, należy przeanalizować w sposób bardziej szczegółowy dwa studia przypadków. W wymiarze „polity” analizowana będzie debata dotycząca europejskiego Traktatu Konstytucyjnego, natomiast w wymiarze „,policy” różne obrazy Europy odnoszące się do wschodniej polityki UE w obliczu wojny na Ukrainie. Obie kwestie są dla Polski bardzo istotne, ponieważ dotyczą z jednej strony, jej siły instytucjonalnej w UE, a z drugiej strony, jednego z jej głównych interesów jako państwa członkowskiego UE. W związku z tym obie debaty polityczne zalicza się do najważniejszych i najbardziej kontrowersyjnych debat europejskich. Ponadto oba studia przypadków odnoszą się do bardziej kontrowersyjnych faz kontestacji i suwerenizmu, co pozwala zakładać odpowiednią polaryzację między partiami politycznymi.

\section{Studium przypadku dotyczące wymiaru ,polity”: debata dotycząca Traktatu ustanawiającego Konstytucję dla Europy}

W przeciwieństwie do wielu innych debat ratyfikacyjnych o treści Traktatu ustanawiającego Konstytucję dla Europy dyskutowano w Polsce faktycznie nie tylko w parlamencie, ale stał się on również tematem szerszej debaty publicznej. Intensywność tej dyskusji była stosunkowo duża, co było właściwie wynikiem silnego odrzucenia jego poszczególnych elementów i retorycznej ostrości argumentów przeciwników traktatu. Celem niniejszego studium przypadku jest zbadanie debaty na temat tej reformy na płaszczyźnie ,polity” w odniesieniu do polaryzacji jako centralnego wymiaru upolitycznienia UE w polskim dyskursie politycznym.

W odniesieniu do tworzenia się preferencji wśród polskich partii politycznych istotne jest tło powstania projektu Traktatu Konstytucyjnego. Polska jako kraj kandydujący do UE była wprawdzie reprezentowana w Konwencie Europejskim z taką samą liczbą przedstawicieli jak państwa członkowskie, ale nie była uprawniona do głosowania. W związku z tym nie mogła interweniować już w fazie negocjacji, co było negatywnie komentowane w debacie krajowej. Jednak doszukiwanie się w tym przyczyn odrzucenia projektu traktatu podczas Konferencji Międzyrządowej w roku 2003 lub zawieszenia jego ratyfikacji w roku 2005 byłoby pochopne. Obok niezdecydowanych, nowych państw członkowskich (jak np. Czechy) były bowiem również takie, które prześcigały się w dążeniach, by ratyfikować go jako pierwszy kraj (chociażby Litwa, Węgry czy Słowenia). W porównaniu do tych ostatnich krajów, krajowy spór polityczny w Polsce przebiegał zdecydowanie bardziej burzliwie ${ }^{12}$.

Po pierwsze, można stwierdzić konsensus ponadpartyjny w określonych postulatach. Wszystkie partie były krytycznie nastawione do zasady podwójnej większości jako sys-

${ }_{12}$ Porównanie debat dotyczących ratyfikacji w poszczególnych państwach członkowskich UE przedstawił B. Maurer 2006, Instytut Polityki Europejskiej 2006 oraz Einhäuser, Salborn, 2006. 
temu głosowania w Radzie Ministrów i do braku odniesienia do Boga w preambule Traktatu Konstytucyjnego. Pierwsze można wytłumaczyć faktem, że Niemcy były niewątpliwie największym beneficjentem reformy systemu głosowania. Był tu widoczny wszechobecny strach w polityce polskiej przed ponowną hegemonią niemiecką w Europie. Drugi aspekt ma uzasadnienie w znaczeniu wiary chrześcijańskiej dla samoświadomości III RP i Kościoła od końca epoki peerelowskiej. Z tych dwóch diagnoz partie polityczne wyciagnęły jednak bardzo odmienne wnioski.

Inną cechą ponadpartyjną było podzielane wspólnie stanowisko w sprawie formy ratyfikacji Traktatu Konstytucyjnego, do której dążono przed negatywnymi w tej sprawie referendami we Francji i w Holandii. Z różnych powodów wszystkie partie opowiadały się za referendum. Podczas gdy partie prawicowo-konserwatywne ze względu na swoją suwerenistyczną argumentację praktycznie nie mogły ukrywać przed społeczeństwem tego, że opowiedziały się za oddelegowaniem suwerenności do instytucji ponadnarodowych, partie lewicowo-liberalne poprzez swoją kampanię na rzecz Traktatu Konstytucyjnego liczyły w obliczu szerokiego poparcia wśród społeczeństwa na zyskanie popularności. Niezależnie od tych cech wspólnych debata na temat traktatu była jednak bardzo kontrowersyjna. $\mathrm{W}$ dodatku na krótko przed jej rozpoczęciem pozytywnie zaopiniowano w referendum akcesyjnym aktualny stan integracji i szybko podjęta tego typu parlamentarna rewizja warunków członkostwa Polski w UE oznaczałaby w oczach wielu polskich polityków zignorowanie wyrażonej wcześniej woli narodu.

Punktem wyjścia dla debaty ratyfikacyjnej było zaakceptowanie w czerwcu 2004 roku przez rząd SLD na czele z Markiem Belką odrzuconego jeszcze przez premiera Millera Traktatu Konstytucyjnego pod warunkiem, że podwójną większość podwyższono by w taki sposób, że zamiast 50\% państw członkowskich reprezentujących $60 \%$ ludności UE kworum stanowiłyby odpowiednio proporcje 55\% do $65 \%$. Nie jest więc zaskakujące, że koalicja rządowa zabiegała o przyjęcie wynegocjowanego kompromisu. Jednocześnie SLD podkreślał, że możliwe jest także dalsze funkcjonowanie na zasadach prawnych określonych w traktacie nicejskim (IEP, 2006, s. 84). Główny wydźwięk tej raczej defensywnej argumentacji można określić jako pragmatyczne wsparcie. Ówczesny minister spraw zagranicznych Włodzimierz Cimoszewicz argumentował, że niektóre elementy traktatu nie wywołują ,,wielkiej radości”, ale należy go ratyfikować na rzecz większej zdolności działania UE („Trybuna”, 2004). Podobnie wyraził się ówczesny prezydent Aleksander Kwaśniewski, który ostrzegał, że nie ratyfikując traktatu Polska zostanie na „szarym końcu” w UE (PAP, 2005). SLD poparł jednoznacznie wzmocnienie Wspólnej Polityki Zagranicznej i Bezpieczeństwa (WPZiB) oraz przewidziane „podwójne obsadzenie" (IEP, 2006, s. 85) ${ }^{13}$. Chwalono przede wszystkim fakt, że Traktat Konstytucyjny zapewniłby jednolity i bardziej czytelny dokument stanowiący podstawę dla UE („Trybuna”, 2004).

Znacznie bardziej krytycznie wypowiedziało się kierownictwo PO. Podczas, gdy przewodniczący partii Donald Tusk postrzegał w Traktacie Konstytucyjnym osłabienie pozycji Polski (PAP, 2004), przewodniczący klubu parlamentarnego Jan-Maria Rokita

13 „Podwójne obsadzenie” polega na tym, że dana osoba pełni dwie funkcje w różnych instytucjach, w tym przypadku urząd Komisarza ds. Stosunków Zewnętrznych (jako przedstawiciel Komisji Europejskiej) oraz Wysokiego Przedstawiciela Unii ds. Wspólnej Polityki Zagranicznej i Bezpieczeństwa (jako przedstawiciel Rady Ministrów). 
krytykował, że dokument ten nie daje odpowiedzi na podstawowe wyzwania europejskie (Einhäuser, 2005). Wpływowy eurodeputowany Jacek Saryusz-Wolski określił nawet Traktat Konstytucyjny jako ,zły, biurokratyczny dokument, który nie leży w interesie obywateli. Jeśli poddamy niniejszy traktat głosowaniu obywateli, naruszymy zasady demokracji”" (Saryusz-Wolski cytowany przez Vettera, 2005, s. 110). Po tym jak PO początkowo jeszcze nie mogła się wyraźnie zdecydować co do jednoznacznej oceny Traktatu Konstytucyjnego (PAP, 2005b), z początkiem 2005 roku nastąpił według Bronisława Komorowskiego zwrot w tej kwestii - PO zaczęła bowiem „bez entuzjazmu” popierać Traktat (PAP, 2005c). W tej sposób PO przyjęła tendencyjnie bardziej krytyczną pozycję w europejskiej debacie politycznej niż można byłoby wnioskować z tradycyjnie pro-europejskiego obrazu partii. Można to uzasadniać wprawdzie notorycznie eurosceptyczną postawą przewodniczącego klubu parlamentarnego, ale może to również wynikać z tego, że gwałtowne odrzucenie podwójnej większości w okresie przygotowań do konferencji międzyrządowej w roku 2003 wydawało się korzystne ze względów demoskopijnych. W końcu polityka taka może być interpretowana także jako klasyczna walka pomiędzy dwoma odłamami partii - obozem konserwatywnym i liberalnym - w której ostatecznie wygrał ten ostatni. W odniesieniu do treści traktatu PO akceptowała co prawda rozszerzenie decyzji większościowych i wzmocnienie WPZiB (IEP, 2006, s. 85), ale postrzegała krytycznie, podobnie jak inne partie, podział głosów w Radzie i brak odniesienia do Boga (PAP, 2005d). Zakwestionowano także określenia o charakterze państwowym takie jak ,konstytucja” (IEP, 2006b, s. 50).

Polskie Stronnictwo Ludowe (PSL) było niezdecydowane. $\mathrm{Z}$ jednej strony musiało bezpośrednio konkurować z lewicowo-populistyczną i euro-krytyczną SRP o raczej wiejski i początkowo euro-sceptyczny elektorat. Z drugiej strony po przystapieniu Polski do UE w obliczu dużych subwencji rolnych nastawienie polskich rolników do integracji było jednak coraz bardziej pozytywne. PSL utworzyło ponadto koalicję z proeuropejskim SLD i wynegocjowało przy tym traktat akcesyjny. W odniesieniu do Traktatu Konstytucyjnego można zaobserwować zatem pewną tendencję od stanowiska nieco krytycznego do neutralnego (Einhäuser, 2005). Zamiast angażować się w debatę na temat konkretnych elementów Traktatu Konstytucyjnego, podkreślano z reguły, że tak wrażliwa decyzja dotycząca suwerenności powinna być rozstrzygana w referendum (PAP, 2005e).

SRP nie przedstawiła żadnego projektu ustawy w sprawie Traktatu Konstytucyjnego. Przypuszcza się, że wynikało to z braku ekspertyzy w zakresie kwestii europejskich, ale także $\mathrm{z}$ wewnętrznego rozdarcia podobnego do tego w PSL. Ostatecznie pierwotne zdecydowanie eurosceptyczne nastawienie SRP drastycznie przechyliło się w kierunku wyraźnego poparcia dla członkostwa w UE.

Wierny swojemu obrazowi Europy PiS nie zakwestionował członkostwa Polski w UE, ale jego pogłębienie. Był zatem sceptycznie nastawiony do umocnienia znaczenia instytucji ponadnarodowych, wzmocnienia WPZiB i rozszerzenia decyzji większościowych - a tym bardziej podwójnej większości (IEP, 2006a, s. 85 i 275). Wyróżniała się przy tym alarmująca retoryka, widoczna chociażby w wypowiedzi Jarosława Kaczyńskiego, że wraz z przyjęciem Traktatu Konstytucyjnego dojdzie do „wprowadzenia hegemonii niektórych najpotężniejszych państw kosztem równości wszystkich członków UE" (PAP, 2004). Z konserwatywnego nastawienia i akcentowania chrześcijańskiego 
dziedzictwa Polski wynikała również ostra krytyka braku odniesienia do Boga w preambule oraz w Europejskiej Karcie Praw Podstawowych (IEP, 2006b, s. 50).

Najbardziej krzykliwy głos w obozie partii eurosceptycznych słychać było jednak ze strony LPR. Biorąc pod uwage, że LPR odrzucała już samo członkostwo w UE, nie zaskakuje fakt, że jako bardzo konserwatywna i nacjonalistyczna partia upatrywała w traktacie konstytucyjnym śmiertelny cios dla niezależnej Polski i sprzeczność z konstytucją RP (PAP, 2005f). Jako warunek dla koalicji rządowej podawała renegocjację Traktatu Konstytucyjnego, za czym jednak później już nie obstawała. W przeciwieństwie do SRP krytyka z jej strony nie dotyczyła wcale całościowo i konkretnie treści traktatu: LPR odrzucała prymat prawa europejskiego nad prawem krajowym („Rzeczpospolita”, 2004), brak odniesienia do Boga w preambule (PAP, 2004b), wzmocnienie WPZiB oraz - w odniesieniu do Karty Praw Podstawowych UE - zakaz dyskryminacji ze względu na orientację seksualną („Nasz Dziennik”, 2004).

Ponieważ 73\% badanych, w grudniu 2004 roku, Polaków wyraziło poparcie dla Traktatu Konstytucyjnego, a wskaźniki aprobaty spadły drastycznie (ale tylko na krótko) do $40 \%$ dopiero po negatywnych referendach we Francji i Holandii, rządzący SLD opowiadał się za szybką ratyfikacją traktatu razem z wyborami prezydenckimi, nie tylko po to, aby móc wykorzystać ten popularny temat w grze wyborczej, ale również w celu zapewnienia niezbędnej dla referendów 50-procentowej frekwencji. Bardziej sceptyczne partie opozycyjne opowiadały się z tych samych powodów za możliwie późnym i oddzielonym od wyborów prezydenckich referendum. Widać tutaj zatem, że w polskiej debacie dotyczącej Traktatu Konstytucyjnego rolę odgrywały również aspekty władzy politycznej.

Warto wreszcie jeszcze dokonać porównania przytoczonych argumentów z rzeczywistym stosunkiem głosowania w Parlamencie Europejskim w styczniu 2005 roku: Podczas gdy SLD głosował jednogłośnie za przyjęciem Traktatu Konstytucyjnego, przedstawiciele PiS i LPR odrzucili go. Jak niezdecydowane były w tej kwestii pozostałe partie pokazują rozbieżne wyniki głosowania: spośród 15 deputowanych PO wszyscy z wyjątkiem jednego, który głosował „za”, wstrzymali się od głosu. Dwóch z trzech deputowanych PSL głosowało negatywnie, jeden wstrzymał się od głosu; za to dwóch przedstawicieli SRP głosowało za traktatem, a czterech wstrzymało się od głosu. Zaskakujący jest zwłaszcza ten ostatni wynik, biorąc pod uwagę pierwotną zdecydowanie antyeuropejską retorykę SRP. Podsumowując Polska razem z Czechami wyróżnia się w porównaniu z innymi krajami najwyższym wskaźnikiem głosów negatywnych oraz tym, że jako jedyny kraj głosowała w większości przeciwko rewizji Traktatu.

\section{Studium przypadku dotyczące wymiaru ,policy”: debata dotycząca polityki wschodniej podczas wojny na Ukrainie}

Od wybuchu konfliktu na Ukrainie w roku 2014 polskie dyskursy europejskie skupiały się na wpływach Polski w UE. Po raz pierwszy od kilkudziesięciu lat Polska została skonfrontowana z konfliktem zbrojnym w swoim bezpośrednim sąsiedztwie. Zasadniczo większość partii zasiadających w Sejmie popierała politykę wschodnią rządu Donalda Tuska (do września 2014 roku), a następnie rządu Ewy Kopacz (od września 2014 roku 
do listopada 2015 roku), gdyż oba rządy PO nakłaniały do polityki powstrzymania Rosji oraz do wsparcia dla Ukrainy w UE i NATO. Polska wraz ze Szwecją i krajami bałtyckimi, a w późniejszej fazie konfliktu także z Niemcami, zaliczała się do głównych inicjatorów wprowadzenia sankcji wobec Rosji. W swoim przemówieniu wygłoszonym w Sejmie w dniu 8.05.2014 roku minister spraw zagranicznych Radosław Sikorski (2014) podkreślił w odniesieniu do głównych założeń polskiej polityki zagranicznej znaczenie Partnerstwa Wschodniego w ramach UE, które powstało z inicjatywy Polski oraz przy wsparciu Szwecji, a następnie zostało poparte przez większość państw członkowskich UE. Sikorski zaznaczył, iż bez Partnerstwa Wschodniego nie byłaby możliwa spójna polityka UE wobec Europy Wschodniej.

Jednocześnie zwrócił uwagę na poważne braki w polityce sąsiedztwa UE, w której widać było wielokrotnie brak solidarności i reprezentowanie własnych interesów przez niektóre państwa członkowskie. Niemniej jednak Sikorski zauważył w imieniu swojej partii, czyli PO, że Polska poprzez swoje zaangażowanie przyczyniła się do ukształtowania podmiotowości UE w polityce zagranicznej, a tym samym stała się jej nieodzowną częścią. Koncepcja ta była kontynuowana od września 2014 roku przez następcę Sikorskiego - Grzegorza Schetynę. Dla niego polska polityka zagraniczna stanowiła również integralną część Wspólnej Polityki Zagranicznej i Polityki Bezpieczeństwa UE, która stała się jeszcze bardziej istotna w wyniku wojny na Ukrainie. Dotyczyło to również zaangażowania UE na Ukrainie. Dla Schetyny (2016) „Kijowski Majdan stał się początkiem nowoczesnej europejskiej tożsamości narodu ukraińskiego".

Przy uwzględnieniu tych faktów widać, że od czasu przejęcia władzy w 2007 roku stanowisko PO przesuwa się w kierunku modelu federacji. Czołowi politycy PO nie tylko postrzegają członkostwo w UE jako skuteczne narzędzie dające Polsce większe znaczenie w polityce zagranicznej, ale rozpoznają przede wszystkim znaczący potencjał dla Warszawy do efektywnego udziału w rozwoju agendy UE w polityce wschodniej. Przemówienie Sikorskiego w Sejmie (2014) pokazało, że jednym z głównych celów PO stało się wypracowanie dla Polski statusu wiarygodnego partnera w UE, który nie tylko przestrzega wartości UE, ale nieustannie postuluje za europejską solidarnością. W tym kontekście kluczową rolę odegrały Niemcy, co dało się zauważyć już w wypowiedziach Sikorskiego w Berlinie w 2011 roku. Podczas wykładu w Niemieckim Towarzystwie Polityki Zagranicznej (DGAP) w listopadzie 2011 roku przypisał on Niemcom status „niezbędnego narodu" w Europie, co wywoływało niekiedy dyskomfort nawet u niemieckich polityków jak np. ministra spraw zagranicznych Franka-Waltera Steinmeiera (SPD) (Steinmeier, 2016). Sikorski opowiedział się przy tym za zwiększeniem niemieckiego przywództwa w Europie oraz rozszerzeniem kompetencji dla Komisji Europejskiej, wzmocnieniem Parlamentu Europejskiego i dalszą demokratyzacją UE.

W tym kontekście widać wyraźny kontrast do wypowiedzi polityków PO z lat 2004 i 2005, które można było wtedy przypisać bardziej do modelu współpracy (Tusk, 2014). PO była nadal przywiązana do modelu współpracy, ale zmierzała w kierunku modelu federacji, który nabierał znaczenia zwłaszcza od objęcia przez Polskę przewodnictwa w Radzie UE w roku 2011. Przewodnictwo Polski w Radzie UE odgrywało przy tym ważną rolę. Uwidoczniło ono bowiem polskim elitom rządowym - mimo wad strukturalnych (takich jak brak członkostwa w strefie euro) - potencjał współdecydowania ich kraju w UE (Szpunar, 2012). 
Największa ówczesna partia opozycyjna, PiS, opowiadała się co prawda na początku wojny na Ukrainie w roku $2014 \mathrm{w}$ dużym stopniu za wsparciem finansowym Ukrainy i wprowadzeniem sankcji wobec Rosji, była jednak nastawiona krytycznie do wyboru strategii i wobec znaczenia Polski w UE. Jednym z największych krytyków polskiej polityki zagranicznej w Europie Wschodniej był ówczesny poseł PiS i późniejszy minister spraw zagranicznych rządu PiS Witold Waszczykowski. Waszczykowski (2014) zarzucał PO głównie zbyt późną reakcję na wojnę na Ukrainie. Polityka zagraniczna PO w stosunku do Rosji była według niego zbyt krótkowzroczna, ponieważ Rosja już dużo wcześniej, przed rokiem 2014, szantażowała politycznie i wywierała nacisk na Ukrainę. „W 2008 roku całkowicie zbagatelizował pan rosyjską akcję wojskową przeciwko Gruzji. Przerwał pan izolację Rosji i umożliwił rosyjskiemu ministrowi spraw zagranicznych przedstawienie kłamliwej wersji wypadków. Rosja rozwija się i otwiera na świat, przekonywał pan w exposé z $2011 \mathrm{r}$. Minister Ławrow był przyjmowany z honorami na zamkniętych spotkaniach polskich ambasadorów" (Waszczykowski, 2014). Interesujące jest przy tym, że PiS oceniał strategiczne znaczenie Ukrainy i agresywną politykę Rosji tak samo jak PO. Waszczykowski (2014) wyrażał się przy tym jednoznacznie: „Aktywne wspieranie niepodległej i demokratycznej Ukrainy jest również naszą racją stanu”.

Mimo to PO, a zwłaszcza Sikorskiemu, zarzucano zbyt małe zaangażowanie w politykę wschodnią, a przede wszystkim używanie złych instrumentów. Do tych złych instrumentów należało głównie zbyt silne zorientowanie PO na Niemcy. Waszczykowski (2014) zwrócił uwagę na ambiwalentne podejście wielu niemieckich polityków do agresji rosyjskiej na wschodniej Ukrainie i aneksji Krymu oraz przyjazne stosunki byłego kanclerza Niemiec Gerharda Schroedera (SPD) z Wladimirem Putinem. Według Waszczykowskiego stawiało to poważnie pod znakiem zapytania niemieckie zobowiązania w ramach NATO i UE. Krytyka PiS odnosiła się również do współpracy z Francją, zwłaszcza wysłania oddziałów polskich do Mali w celu wsparcia wojsk francuskich w latach 2013 i 2014. Zaangażowanie Polski w Mali skonfrontowano z dążeniami Francji, która podczas trwania wojny na Ukrainie chciała sprzedać Rosji okręty wojenne typu Mistral (Waszczykowski, 2014). Inni politycy PiS byli również krytycznie nastawieni do bezwarunkowego zbliżenia Warszawy do Berlina. Ekspert w polityce zagranicznej PiS, Krzysztof Szczerski, skrytykował PO i Sikorskiego za ich germanofilską politykę europejską: „Twierdzi pan w swoim exposé, że Unia potrzebuje silnego przywództwa. Pan już nawet to przywództwo nazwał i przydzielił tę rolę państwu niemieckiemu, ale dziś, kompletnie wbrew interesom naszej gospodarki, podpisuje się pan pod planami tego właśnie przywództwa, aby zacieśniać unię bankowa, iść ku unii podatkowej, poddać biznes kontroli urzędników z góry" (Szczerski, 2014a).

Przy uwzględnieniu tych faktów staje się oczywiste, że krytyka PiS w kierunku PO w kwestii wojny na Ukrainie jest świadectwem zorientowania na model współpracy. Przedstawiciele rządu PiS podkreślali, że nie uznają wyjścia z UE i dążą do w pełni zintegrowanego udziału Polski w procesie decyzyjnym UE (Szymczuk, 2016). Członkostwo Polski w UE uznano za konieczne, przy czym celem, który chciano osiagnąć, była zrównoważona i przede wszystkim odbywająca się na równych prawach współpraca z kluczowymi krajami UE. ,[UE] przeżywa poważny kryzys koncepcyjny [...]. Nie możemy ulegać presji, że rozwiązań należy poszukiwać tylko w planach federacyjnych i dalszym upolitycznieniu Unii. To może doprowadzić nas do Unii niedemokratycznej, 
kierowanej przez dyrektoriat mocarstw" (Waszczykowski, 2014). Wydaje się przy tym, że model kooperacji posłużył nie tylko jako podstawa krytyki polityki wschodniej PO. W grudniu 2015 roku Waszczykowski (2016) jako minister spraw zagranicznych Polski przedstawił nowe zasady polskiej polityki zagranicznej. Podkreślono przy tym przede wszystkim suwerenność państw członkowskich, którą zaakcentowano jako podstawę funkcjonowania zarówno UE, jak i NATO. Dochodzi do tego wyróżnianie stosunków z Wielką Brytanią przy jednoczesnym wyraźnym umniejszaniu znaczenia Francji i Niemiec. Oprócz wzmocnienia Grupy Wyszehradzkiej PiS postawił sobie ponadto za cel marginalizację Trójkąta Weimarskiego (Polska, Niemcy i Francja) (Szczerski, 2014). Na tej podstawie powstała także koncepcja „Międzymorza” („Intermarium”), będącą dla PiS alternatywą dla francusko-niemieckiego motoru integracji. Koncepcja ta wywodzi się z przedwojennej idei konfederacji państw Europy Środkowo-Wschodniej rozciagającej się od Morza Czarnego do Morza Bałtyckiego (Tarczyński, 2016). PiS obstawał nadal za modelem współpracy, kierował się jednak ku modelowi autonomii, w którym do priorytetów polityki zagranicznej należą bilans sił i unikanie asymetrycznych relacji w UE.

Podczas gdy główne partie polityczne reprezentowane w Sejmie w 2014 roku w różnym stopniu obstawały za modelem współpracy, model federacji był silniej reprezentowany przez lewicowo-liberalny Ruch Palikota (od roku 2013 Twój Ruch). Dla lidera partii Janusza Palikota lekcją z wojny na Ukrainie było to, że NATO, a zwłaszcza Stany Zjednoczone byłyby tylko warunkowo gotowe bronić Polskę przed atakami ze strony Rosji. Rozwiązaniem byłaby zatem większa integracja Polski z UE, np. poprzez przystąpienie do strefy euro. ,Jeśli bowiem dzisiaj Warszawa jest trochę bardziej bezpieczniejsza niż Kijów, to nie dlatego, że jesteśmy w NATO i Unii Europejskiej, tylko dlatego, że wyeksportowaliśmy do Berlina, wymieniliśmy się z Berlinem na kwotę 76 mld euro. Potrzebujemy strefy euro i skoku technologicznego" (Palikot, 2014). Podobne stanowisko reprezentował również Robert Biedroń, członek partii Ruch Palikota, który w wyraźny sposób podnosił kwestię federalizacji UE: „Dlatego naszym nadrzędnym celem musi być Europa, Europa złożona z demokratycznych państw, federacja państw zintegrowanych w ramach UE z silną walutą europejską, Europa chroniąca nas przed zagrożeniami z zewnątrz" (Biedroń, 2014). Także postkomunistyczne SLD pozostawał tendencyjnie bliski modelowi federacji, przy czym brakowało tu wyraźnego odniesienia do federalizacji Europy, a popierano przede wszystkim przystapienie Polski do strefy euro, pełne uznanie unijnej Karty Praw Podstawowych oraz ogólne wzmocnienie UE po wojnie na Ukrainie (Miller, 2014 i 2015). Doszły do tego też postulaty z szeregów SLD, aby podążać za głównym nurtem UE zamiast podejmować inicjatywy w celu zaostrzenia sankcji wobec Rosji (Iwiński, 2014).

Najbliższa modelowi autonomii była partia Kukiz'15, która osiagnęła prawie 9-procentowy wynik w wyborach parlamentarnych w październiku 2015 roku. Ta partia protestu jest zbiorem krytycznie nastawionych do polskiego systemu politycznego i euro-sceptycznych polityków. Lider partii Paweł Kukiz opowiadał się między innymi za referendum w sprawie wyjścia Polski z UE wzorem Wielkiej Brytanii (Szymczuk, 2016) i za zdystansowaną polityką wobec Niemiec. Politycy partii Kukiz'15 nieustannie porównywali UE ze Związkiem Radzieckim i dążyli do ,repolonizacji” Polski (ponowne nabycie udziałów rynkowych międzynarodowych przedsiębiorstw przez państwo polskie 
względnie przez przedsiębiorstwa polskie w celu zwiększenia polskiego kapitału), szczególnie w obliczu faktu, że dużą część mediów polskich kontrolują inwestorzy niemieccy (InteriaFakty, 2016). W marcu 2016 roku powstała grupa parlamentarna Kukiz'15 i PiS, która miała obliczyć bilans zysków i strat obecności Polski w UE. Pod koniec roku miała zostać przedstawiona tzw. „Niebieska Księga”, w której dokonano analizy nieudanych regulacji europejskich, ograniczeń polskiej gospodarki przez UE i ograniczeń wolności nałożonych przez Brukselę (Kośmiński, 2016). W kontekście wojny na Ukrainie Paweł Kukiz reprezentował wyraźnie negatywny obraz Niemiec. Według niego, Niemcy jako kluczowy gracz w UE zdradziły Ukrainę, ponieważ rozbudziły początkowo nadzieje Kijowa na włączenie do UE, a następnie je pogrzebały poprzez plany budowy Gazociągu Północnego z Rosją. „Za 15 lat [Niemcy] sprzedadzą nas [Polskę] Ruskim, jak dziś sprzedali Ukrainę" (Baliszewski, 2014). Z perspektywy Kukiz'15 Niemcy wspierały przystapienie Polski do UE wyłącznie w celu skorzystania z polskiej taniej siły roboczej. Ponieważ w Polsce występował właśnie niż demograficzny i nie mogła ona tym samym w najbliższym czasie eksportować więcej pracowników, straciła w oczach Niemiec na atrakcyjności i wkrótce także na zainteresowaniu na rzecz ściślejszej współpracy z Rosją (Baliszewski, 2014).

Po wyborach w październiku 2015 roku, pozostałe partie reprezentowane w Sejmie przyłączyły się do modelu współpracy z tendencjami federalnymi. „Nowoczesna” Ryszarda Petru pozostała w kwestii wojny na Ukrainie w dużej mierze wierna kierunkowi PO. Petru (2016) zarzucał PiS sceptycyzm wobec UE oraz to, że chce stworzyć sojusz z Wielką Brytanią, co jest problematyczne ze względu na brytyjskie referendum w sprawie wystapienia z UE. Jednocześnie Petru wskazał na ograniczoną użyteczność Grupy Wyszehradzkiej ze względu na fakt, że Węgry i Słowacja należały do głównych zwolenników Moskwy w konflikcie z Ukrainą. Dotyczyło to także PSL, które w wyborach 2015 roku ledwo przekroczyło wymagany próg wyborczy. Nowy szef PSL Władysław Kosiniak-Kamysz (2016) pozostawał również krytycznie nastawiony do nadmiernego akcentowania Grupy Wyszehradzkiej w nowej koncepcji polityki wschodniej PiS. Jego zdaniem, właśnie w kwestii wojny na Ukrainie między Polską, Węgrami, Słowacją i Czechami pojawiło się więcej różnic niż podobieństw.

\section{Podsumowanie}

W niniejszym artykule dokonano analizy upolitycznienia UE na przykładzie polskich partii politycznych w oparciu o koncepcję obrazów Europy. Na płaszczyźnie teoretycznej można stwierdzić, że pojęcie obrazów Europy okazało się przydatnym narzędziem do zbadania zagadnienia upolitycznienia UE. Pomimo słabej strony, wynikającej z tego, że obserwacje empiryczne nie zawsze można dokładnie przypisać do typów idealnych obrazu Europy, ramy analityczne obejmują dynamikę krajowego dyskursu w ujęciu czasowym oraz w odniesieniu do danych partii politycznych i dostarczają informacji na temat polaryzacji wśród uczestników tego dyskursu.

Przypadek Polski potwierdza, że decydującymi podmiotami upolityczniającymi są faktycznie partie polityczne. Poprzez silną polaryzację polskich obrazów Europy mogą one dobrze odzwierciedlać różne nastroje społeczne. Jednakże oprócz partii politycz- 
nych istnieją dwa inne główne podmioty, które również miały wpływ na obrazy Europy. Jest to, po pierwsze, Kościół katolicki, który ma wpływ - choć ambiwalentny - na europejskie debaty polityczne. Przez swoje wezwanie do przystąpienia Polski do UE pochodzący z Polski Papież Jan Paweł II wyrażał się przeciwstawnie do wpływowego przedstawiciela kościoła polskiego i jednocześnie przedsiębiorcy w branży medialnej, ojca Tadeusza Rydzyka, który otwarcie polemizował przeciwko UE. Ponadto obok Kościoła katolickiego od końca 2015 roku ważną rolę odgrywa ruch pozaparlamentarny pod nazwą „KOD” (Komitet Obrony Demokracji). Protestował on głównie w 2015 i 2016 r. w widoczny dla opinii publicznej sposób na ulicach przeciwko polityce PiS.

Jeśli chodzi o klasyfikację partii politycznych wzdłuż osi „TAN” (Hooghe i in. 2004), potwierdza się zakładany trend, że tradycyjne, autorytarne lub nacjonalistyczne partie polityczne są raczej sceptycznie nastawione do integracji. Również polskie partie liberalne (PO, N.) i zielone względnie alternatywne (RP) są znacznie bardziej przyjaźnie nastawione do integracji niż bardziej tradycyjne i zorientowane na państwo narodowe partie (PiS, LPR, SRP, Kukiz'15). Nie jest to również zaskakujące, ponieważ polityka ukierunkowana na własne państwo czy też nawet polityka nacjonalistyczna są trudne do pogodzenia z integracją europejską. Można również potwierdzić, że europejskie debaty polityczne były podejmowane głównie przez partie polityczne krytycznie nastawione do integracji, natomiast w przypadku działań partii proeuropejskich w odniesieniu do UE zaobserwować można aspekt odpolityczniający. W przypadku Polski nie można jednak mówić o tym, że wszystkie partie głównego nurtu unikają europejskich debat politycznych. Co najmniej od 2005 roku PiS należy do głównego nurtu politycznego, zrzesza obecnie - również według sondaży - więcej wyborców niż każda inna partia polityczna i tworzy ponadto sama rząd. Jest on jednak postrzegany jako mniej przyjazny integracji należy go przyporządkować raczej do obozu „TAN” (traditionalist/authoritarian/nationalist) niż „GAL” (green/alternative/libertarian). Co ciekawe, zdecydowana większość zwolenników partii popiera członkostwo w UE, także retoryka PiS stała się znacznie bardziej umiarkowana w porównaniu do lat akcesyjnych.

W odniesieniu do kwestii upolitycznienia na pierwszym planie stoją w niniejszej publikacji dwie debaty, jedna dotycząca europejskiej „,polity”, druga europejskiej ,,policy”. Nawet jeśli debata w wymiarze ,polity” była - w porównaniu do debaty dotyczącej wymiaru „,policy” - prowadzona w sposób wyraźnie bardziej kontrowersyjny i intensywniejszy, nie oznacza to, że wynikało to z większego znaczenia politycznego zagadnień konstytucyjnych. Z jednej strony Partnerstwo Wschodnie UE można w zasadzie zaklasyfikować do wymiaru ,polity”, ponieważ Polska w perspektywie średnioterminowej chce wejścia do UE krajów docelowych - nawet jeśli nie wszystkich, to przynajmniej Ukrainy, a w perspektywie długoterminowej także Mołdowy i Białorusi, przez co zmieniłby się znacząco kształt konstytucyjny UE. Po drugie politykę wschodnią Polski i UE traktuje się jako kwestie priorytetowe, gdyż nieufność do coraz bardziej agresywnie działającej Rosji jest zakodowana głęboko. Suwerenność i integralność terytorialna Ukrainy należy do polskiej racji stanu. Również z powodu ponadpartyjnego i społecznego konsensusu debata ta nie może być zbyt gorąca, ponieważ nie chodzi o kontrowersje wokół celów, ale dużo bardziej o środki do osiagnięcia pożądanego celu. W kontekście polityki wschodniej przedmiotem upolitycznienia stały się przede wszystkim unijne płaszczyzny „policies”, a nie sama UE. Różnice między PO i PiS dotyczyły raczej instrumentów 
polityki wschodniej, a nie umocowania tej polityki w UE. Inne zagadnienia dotyczące polityki europejskiej to pozyskiwanie funduszy unijnych, ewentualne wejście do strefy euro lub „kryzys euro”. Zagadnienia te rzadko osiagały jednak podobną intensywność jak analizowane tutaj kwestie.

Można wreszcie stwierdzić, że spektrum poglądów dotyczących polityki europejskiej wśród partii politycznych w Polsce jest w porównaniu do Niemiec znacznie szersze. Podczas gdy w Niemczech nie ma żadnej partii o poglądach izolacjonistycznych, opowiadającej się za modelem autonomii, a modelowi kooperacji można wyraźnie przyporządkować jedynie AfD, w Polsce partią zdecydowanie opowiadającą się za autonomią była LPR, która nawet współtworzyła w latach 2005-2007 rząd. Do modelu kooperacji można zaliczyć natomiast od roku 2015 nawet większość posłów w polskim Sejmie. Oprócz większej polaryzacji w przeszłości bez wątpienia także w Polsce przez długi czas prowadzono intensywniejsze debaty dotyczące polityki europejskiej. Różnice zmniejszyły się jednak znacznie, gdyż w międzyczasie europejski dyskurs polityczny w Niemczech stał się wyraźnie bardziej kontrowersyjny w obliczu kryzysu związanego z falą uchodźców - ale również już wcześniej w związku z „kryzysem euro” - ze względu na krytyczne głosy ze strony CSU i AfD. Na uwagę zasługuje w Polsce - w przeciwieństwie do niemieckich partii politycznych - wysoka fluktuacja obrazów Europy wśród partii w poszczególnych okresach legislacyjnych. Czy to w przypadku PO, SRP czy też PiS mimo pewnych ciagłości istnieją znaczne wahania w nastawieniu do podstaw polityki europejskiej. W przeciwieństwie do Niemiec w Polsce występuje jedna partia głównego nurtu, która próbuje zintegrować ugrupowania sceptycznie nastawione do polityki europejskiej. Było tak szczególnie w latach 2005-2007, gdy PiS stworzył koalicję rządową z eurosceptycznymi partiami: LPR i SRP, w także w roku 2015, gdy PiS postrzegał nacjonalistyczną partię protestu Kukiz'15 jako potencjalnego młodszego partnera w parlamencie.

Od kilku miesięcy debata dotycząca polityki europejskiej i procedury praworządności zyskały jednak bardzo na znaczeniu. Z przedmiotu Unia Europejska stała się tym samym podmiotem polskiej debaty europejskiej. Partie polityczne i społeczeństwo są w dodatku głęboko podzielone. Pierwotnie krajowa debata polityczna została zeuropeizowana, a polityka europejska stała się polityką wewnętrzną państwa. W przeciwieństwie do debaty na temat Traktatu Konstytucyjnego i Partnerstwa Wschodniego, nie ma tutaj praktycznie żadnej jednomyślności ponadpartyjnej. Pod tym względem obecna debata nasili prawdopodobnie upolitycznienie UE w Polsce.

Należy wreszcie zwrócić uwagę na granice podejścia ukierunkowanego wyłącznie na partie (de Wilde, 2011, s. 569). Partie nie są jedynymi głównymi uczestnikami w europejskim dyskursie politycznym. Jak już wspomniano, szczególnie ważne jest, aby zwrócić większą uwagę na ruch społeczny KOD, ponieważ stał się on od grudnia 2015 roku istotnym przedstawicielem procesów upolityczniania. Chociaż powstał on w odpowiedzi na kontrowersyjne ustawy rządu PiS, to powoływał się w protestach stale na europejską tożsamość Polski i jej członkostwo w UE, z których wynikają standardy państwa prawa. Począwszy od maja 2016 roku KOD demonstrował pod hasłem „Jesteśmy i pozostaniemy w Europie". W tym sensie postawił pytanie o praworządność w Polsce w kontekście europejskim i stał się przez to w roku 2016 centralnym uczestnikiem europejskiego dyskursu politycznego w Polsce (Karolewski, 2016). Tym samym debata dotycząca polityki 
europejskiej w Polsce prowadzona była nie tylko między partiami politycznymi. Biorąc pod uwagę inicjatywę GeenPeil w Holandii, opowiadającą się za odrzuceniem umowy o stowarzyszeniu UE z Ukrainą, fakt, że procesy upolitycznienia mogą być forsowane - oprócz tradycyjnych partii politycznych - także przez inne podmioty można interpretować jako bardziej powszechne zjawisko.

\section{Bibliografia}

Baliszewski T. (2014), Pawet Kukiz: Niemcy sprzedadzq nas Ruskim, jak dziś sprzedali Ukrainę, http:// natemat.pl/92843,pawel-kukiz-niemcy-sprzedadza-nas-ruskim-jak-dzis-sprzedali-ukraine, 16.7.2016.

Biedroń R. (2014), Wypowiedź na posiedzeniach Sejmu. Posiedzenie nr 79 w dniu 6.11.2014, http:// www.sejm.gov.pl/sejm7.nsf/wypowiedz.xsp?posiedzenie=79\&dzien=2\&wyp=99\&view=1, 16.7.2016.

Closa C. (2006), The Ratification Process in Poland, http://www.unizar.es/euroconstitucion/Treaties/ Treaty_Const_Rat_poland.htm, 16.7.2016.

Diez T. (1999), Die EU lesen. Diskursive Knotenpunkte in der britischen Europadebatte, VS Verlag, Wiesbaden.

Einhäuser B., Salborn G. V. (2006), Der Ratifizierungsstand zum Europäischen Verfassungsvertrag. Sachstand und Stimmungen in den einzelnen Mitgliedstaaten der Europäischen Union, Juni 2006, http://www.kas.de/proj/home/pub/9/1/year-2006/dokument_id-8595/index.html, 9.10.2006.

Fischer T., Metz A. (2004), Mit Nizza am Abgrund? Die Institutionen der EU-25 nach dem gescheiterten Brüsseler Verfassungsgipfel, Centrum für angewandte Politikforschung, Reform-Spotlight, nr 1, http://www.cap.lmu.de/download/spotlight/Reformspotlight_01-04_d.pdf, 16.7.2016.

Flis J. (2012), Recht und Gerechtigkeit (PiS) - unkoordinierter Flügelschlag, „Polen-Analysen” 117, $\mathrm{http}: / / w w w . l a e n d e r-a n a l y s e n . d e / p o l e n / p d f / P o l e n A n a l y s e n 117 . p d f, 16.7 .2016$.

Gaisbauer H. P. (2005), Polen und der Verfassungsvertrag in der IGC 2003 - ein klassisches two level game?, „Österreichische Zeitschrift für Politikwissenschaft”, nr 34(3), s. 295-310.

Gaisbauer H. P. (2006), Ideologie oder Strategie? Polnischer Euroskeptizismus nach dem EU-Beitritt, „Österreichische Zeitschrift für Politikwissenschaft”, nr 35(2), s. 173-188.

Gaisbuer H. P. (2008), Polens Vorstellungen zur künftigen Gestalt der EU und dem Grad polnischdeutscher Kooperation, w: Deutschland und Polen. Die europäische und internationale Politik, red. T. Jäger, D. W. Dylla, VS Verlag, Wiesbaden, s. 57-79.

Grieco J. (1996), State Interests and Institutional Rule Trajectories: A Neorealist Interpretation of the Maastricht Treaty and European Economic and Monetary Union, „Security Studies”, nr 5(3), s. 261-306, DOI:10.1080/09636419608429281.

Grimm D. (2015), The Democratic Costs of Constitutionalisation: The European Case, „European Law Journal", nr 21(4), s. 460-473, DOI: 10.1111/eulj.12139.

Hahn I. (2007), Polen und „Europa”. Europabilder und nationale Identität im Beitrittsprozess zur Europäischen Union, Wrocław ATUT. Institut für Europäische Politik (2006b, ed.), EU-25 Watch, nr 3, Berlin, nieopublikowany fragment pracy dotyczący Finlandii autorstwa Artturi Virkkunen i Kristi Raik, przesłany drogą elektroniczną w dniu 28.06.2016 przez Hannę Ojanen, http:// www.eu-27watch.org/?q=node/30, 16.7.2016.

IEP (Institut für Europäische Politik) (2006a, ed.), EU-25 Watch, nr 2, January 2006, Berlin, dostępny w World Wide Web: http://www.eu-27watch.org/?q=taxonomy/term/2, 16.7.2016.

Interiafakty (2016), Kukiz: Unia Europejska gorsza niz Zwiqzek Sowiecki, http://fakty.interia.pl/tylkou-nas/news-kukiz-unia-europejska-gorsza-niz-zwiazek-sowiecki,nId,1949104, 16.7.2016.

Ipsen H. P. (1972), Europäisches Gemeinschaftsrecht, Mohr, Tübingen. 
Jachtenfuchs M. (2002), Die Konstruktion Europas. Verfassungsideen und institutionelle Entwicklung, Nomos, Baden-Baden.

Jachtenfuchs M., Diez T., Jung S. (1998), Which Europe? Conflicting Models of a Legitimate European Political Order, „European Journal of International Relations”, nr 4(4), s. 409-445.

Jung S. (1999), Europa, made in France. Eine Analyse des politischen Diskurses Frankreichs zur Zukunft der Europäischen Gemeinschaft - von den Anfängen bis heute, Nomos, Baden-Baden.

Kaczyński J. (2003), Konwencja konstytucyjna Prawa i Sprawiedliwości. Wystapienie prezesa PiS Jarosława Kaczyńskiego, Warszawa, http://old.pis.org.pl/doc.php?d=unit\&id=23, 16.7.2016.

Karolewski I. P. (2016), Protest and participation in post-transformation Poland: The case of the Committee for the Defense of Democracy, „Communist and Post-Communist Studies”, nr 49(3), s. 1-13, DOI: 10.1016/j.postcomstud.2016.06.003.

Karolewski I. P., Benedikter R. (2016a), Poland's Conservative Turn and the Role of the European Union, „European Political Science”, DOI: 10.1057/s41304-016-0002-x, im Erscheinen.

Karolewski I. P., Benedikter R. (2016b), Poland's conservative turn of 2015: Where are its real origins?, CIFE Policy Paper 35, Centre international de formation européenne, http://www.cife. eu/Ressources/FCK/files/publications/policy\%20paper/CIFE_PP35_Polands_conservative_ turn_of_2015_Karolewski_Benedikter_2016.pdf, 16.7.2016.

Karolewski I. P., Mehlhausen T., Sus M. (2014, red.), Polandźs EU-Council Presidency unter Evaluation. Navigating Europe through Stormy Waters, Nomos, Baden-Baden.

Kassim H., Menon A. (2003), The principal-agent approach and the study of the European Union: promise unfulfilled?, „Journal of European Public Policy”, nr 10(1), s. 121-139, DOI: 10.1080/1350176032000046976.

Kosiniak-Kamysz W. (2016), Wypowiedź na posiedzeniach Sejmu. Posiedzenie nr 10 w dniu 29.01.2016, http://orka2.sejm.gov.pl/StenoInter8.nsf/0/6A4CD2F71231A36FC1257F4D003FECA4/\%24F ile/10_b_ksiazka_bis.pdf, 16.7.2016.

Kośmiński P. (2016), Pawłowicz z posłami Kukiz'15 będzie wyliczać, ile Polska traci na członkostwie w Unii, http://wyborcza.pl/1,75398,19781008,pawlowicz-z-poslami-kukiz-15-bedzie-wyliczac-ile-polska-traci.html, 16.7.2016.

Larsen H. (1997), Foreign policy and discourse analysis: France, Britain and Europe, Routledge, London.

Marcussen M., Risse T., Engelmann-Martin D., Knopf H.-J., Roscher K. (2001), Constructing Europe? The Evolution of Nation-State Identities, w: The Social Construction of Europe, red. T. Christiansen, K. E. Jørgensen, A. Wiener, Sage, London, s. 101-120.

Maurer A. i in. (2006), Ratifikationsverfahren zum EU-Verfassungsvertrag, Stiftung für Wissenschaft und Politik, http://www.swp-berlin.org/de/common/get_document.php?id=1135, 16.7.2016.

Mehlhausen T. (2009), Der Streit um die doppelte Mehrheit. Deutsch-polnische Differenzen in der Europapolitik, w: Zwischen Skepsis und Vertrauen. Die deutsch-polnischen Beziehungen im Wandel, red. K. Mazurek, T. Mehlhausen, Wydawnictwo Uniwersytetu Jagiellońskiego, Kraków, s. 155-165.

Miller L. (2014), Wypowiedź na posiedzeniach Sejmu. Posiedzenie $n r 79$ w dniu 6.11.2014, http:// www.sejm.gov.pl/Sejm7.nsf/wypowiedz.xsp?posiedzenie=79\&dzien=2\&wyp=98\&view=2, 16.07.2016.

Miller L. (2015), Wypowiedź na posiedzeniach Sejmu. Posiedzenie nr 91 w dniu 23.04.2015, http:// www.sejm.gov.pl/Sejm7.nsf/wypowiedz.xsp?posiedzenie=91\&dzien=2\&wyp=41\&view=2, 16.07.2016.

Moravcsik A. (1998), The Choice for Europe: Social Purpose and State Power from Messina to Maastricht, Cornell University Press, Ithaca.

Münch H. (2007), Leitbilder und Grundverständnisse der polnischen Europapolitik, Springer VS, Wiesbaden.

„Nasz Dziennik” (2004), Kolejny krok ku eurototalitaryzmowi, 30.10.-1.11. 
Palikot J. (2014), Wypowiedź na posiedzeniach Sejmu. Posiedzenie 67 w dniu 8.05.2014, http:// www.sejm.gov.pl/Sejm7.nsf/wypowiedz.xsp?posiedzenie=67\&dzien=2\&wyp=88\&view=2, 16.07.2016.

PAP (Polska Agencja Prasowa) (2004), Postowie odrzucili projekt uchwaty LPR ws. Unijnej konstytucji, 3.12.2004.

PAP (Polska Agencja Prasowa) (2004b), Parlament Europejski popart unijnq konstytucje, 30.10.1.11.2004.

PAP (Polska Agencja Prasowa) (2005a), Kwaśniewski: Traktat Konstytucyjny UE, to możliwość szybszej integracji Unii, 20.01.2005.

PAP (Polska Agencja Prasowa) (2005b), Ratyfikacja konstytucji UE - w referendum, 20.01.2005.

PAP (Polska Agencja Prasowa) (2005c), Komorowski: absolutna większość PO poprze unijna konstytucje, 18.01.2005.

PAP (Polska Agencja Prasowa) (2005d), Saryusz-Wolski: Referendum później, tym lepiej, 12.01.2005.

PAP (Polska Agencja Prasowa) (2005e), Pawlak: Traktat Konstytucyjny daje nam rolę hamulcowego, 21.01.2005.

Petru R. (2016), Wypowiedź na posiedzeniach Sejmu. Posiedzenie nr 10 w dniu 29.01.2016, http:// orka2.sejm.gov.p1/StenoInter8.nsf/0/6A4CD2F71231A36FC1257F4D003FECA4/\%24File/10 _b_ksiazka_bis.pdf, 16.07.2016.

Prawo i Sprawiedliwość (2011), Nowoczesna, solidarna, bezpieczna Polska. Program Prawa i Sprawiedliwości, Warszawa, http://old.pis.org.pl/download.php?g=mmedia\&f=program_pis_2009. pdf, 16.7.2016.

Risse T. (2000), „Let's Argue”: Communicative Action in World Politics, „International Organization”, nr 54(1), s. 1-39.

Risse T., Engelmann-Martin D., Knopf H.-J., Roscher K. (1999), To Euro or Not to Euro?: The EMU and Identity Politics in the European Union, „European Journal of International Relations”, nr 5(2), s. 147-184.

„Rzeczpospolita” (2004), Czy poprzeć konstytucję Europy, 3.12.2004.

Scharpf F. (1999), Governing in Europe: Effective and Democratic?, Oxford University Press, Oxford.

Schetyna G. (2016), Wypowiedź na posiedzeniach Sejmu Posiedzenie nr 91 w dniu 23.04.2015, http:// www.sejm.gov.pl/Sejm7.nsf/wypowiedz.xsp?posiedzenie=91\&dzien=2\&wyp=37\&view=2, 16.7.2016.

Sikorski R. (2011), Polen und die Zukunft der Europäischen Union, Rede am 28.11.2011, Berlin, http:// berlin.msz.gov.pl/resource/20e5da7c-594f-4186-a52a-5857559ed956, 16.07.2016.

Sikorski R. (2014), Informacja ministra spraw zagranicznych o założeniach polskiej polityki zagranicznej w 2014 roku, http:/www.sejm.gov.pl/Sejm7.nsf/wypowiedz.xsp?posiedzenie=67\&dzien=2 $\&$ wyp $=83 \&$ view $=2,16.7 .2016$.

Steinmeier F.-W. (2016), Germany's New Global Role: Berlin Steps Up, „Foreign Affairs”, July/August 2016 Issue, https:/www.foreignaffairs.com/articles/europe/2016-06-13/germany-s-newglobal-role, 16.7.2016.

Szczerski K. (2014a), Wypowiedź na posiedzeniach Sejmu. Posiedzenie nr 67 w dniu 8.05.2014, http:// www.sejm.gov.p1/Sejm7.nsf/wypowiedz.xsp?posiedzenie=67\&dzien=2\&wyp=93\&view=2, 16.07.2016.

Szczerski K. (2014b), Wypowiedź na posiedzeniach Sejmu. Posiedzenie nr 79 w dniu 6.11.2014, http:// www.sejm.gov.pl/Sejm7.nsf/wypowiedz.xsp?posiedzenie=79\&dzien=2\&wyp=99\&view=2, 16.07.2016.

Szpunar M. (2012), Wypowiedź na posiedzeniach Sejmu. Posiedzenie nr 16 w dniu 14.06.2012, http:// www.sejm.gov.pl/Sejm7.nsf/wypowiedz.xsp?posiedzenie=16\&dzien=2\&wyp=103\&view=2, 16.07.2016.

Szymczuk M. (2016), Kukiz'15 rozważa referendum ws. wystapienia Polski z UE, http://wiadomosci.wp.pl/kat,1342,title,Kukiz15-rozwaza-referendum-ws-wystapienia-Polski-z-UE- 
Kulesza-chcemy-zeby-Polska-byla-traktowana-przynajmniej-na-rowni-z-innymi-panstwami,wid,18146306,wiadomosc.html?ticaid=1173db\&_ticrsn=3, 16.07.2016.

Tarczyński D. (2016), Wypowiedź na posiedzeniach Sejmu. Posiedzenie nr 10 w dniu 29.01.2016, http:// orka2.sejm.gov.pl/StenoInter8.nsf/0/6A4CD2F71231A36FC1257F4D003FECA4/\%24File/10 _b_ksiazka_bis.pdf, 16.07.2016.

„Trybuna” (2004), Integracja Europejska, 1.11.2004.

Tusk D. (2014), Wypowiedź na posiedzeniu Sejmu. Posiedzienie nr 67 w dniu 8.05.2014, http:// www.sejm.gov.pl/Sejm7.nsf/wypowiedz.xsp?posiedzenie=67\&dzien=2\&wyp=86\&view=2, 16.07.2016.

Vetter R. (2005), Wer sind die wahren Europäer? Osteuropa und die EU-Krise, „Osteuropa”, nr 55, s. 103-116.

Vetter R. (2015), Von Kaczyńskis Gnaden. Die neue nationalkonservative Regierung, Polen-Analysen 173 , s. $2-8$.

Wagner W. (2002), Die Konstruktion einer europäischen Außenpolitik: deutsche, französische und britische Ansätze im Vergleich, Campus, Frankfurt a.M.

Waltz K. (1979), Theory of international politics, McGraw-Hill, Boston i in.

Waszczykowski W. (2014), Wypowiedź na posiedzenu Sejmu. Posiedzenie nr $67 \mathrm{w}$ dniu 8.05.2014, http://www.sejm.gov.pl/Sejm7.nsf/wypowiedz.xsp?posiedzenie=67\&dzien=2\&wyp=85\&vie $\mathrm{w}=2,16.07 .2016$.

Waszczykowski W. (2016), Informacja ministra spraw zagranicznych o zatożeniach polskiej polityki zagranicznej w 2016 r., http://www.mfa.gov.pl/pl/aktualnosci/wiadomosci/minister_witold_ waszczykowski_o_priorytetach_polskiej_dyplomacji, 16.07.2016.

Wendt A. (1992), Anarchy Is What States Make of It, „International Organization”, nr 46, s. 391-425. Wendt A. (1999), Social Theory of International Politics, Cambridge University Press, Cambridge i in.

\title{
Between participation demand and self-assertion. Polish debates on the European constitutional treaty and the war in Ukraine
}

\begin{abstract}
Summary
The chapter explores politicisation using the example of the images of Europe within the political discourse of the Third Polish Republic (1990-2016). Based on consecutive phases of Poland's EU politics (adaptation, contestation, cooperation and sovereigntism) the chapter argues that the phases cannot be explained with changing domestic power constellations alone. Therefore, the chapter scrutinizes the dynamics of the images of Europe in Poland, since these images can correlate with varying politicisation potentials. First, the chapter presents the theoretical approach focusing on the concept of the images of Europe. Next, two case studies with a high degree of polarisation are examined, as they can be attributed to the phases of confrontation and sovereigntism: the debate on the European constitutional treaty of 2005 and the Eastern policy in the course of the war in Ukraine in 2014. The case of Poland supports the hypothesis that political parties are the primary agents of politicisation. On the one hand, as a result of high polarisation of the images of Europe diverging political positions within the population can be reflected more visibly at the level of the political elites. On the other hand, polarisation can increase the volatility of the images of Europe even within one party, thus increasing the politicisation dynamics.
\end{abstract}

Key words: Polish debates on Europe, images of Europe, political parties, politicisation, political polarization, war in Ukraine, European constitutional treaty 